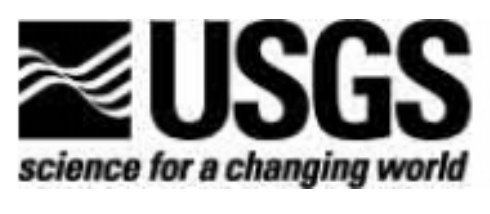

\title{
Coastal Vulnerability Assessment of Channel Islands National Park (CHIS) to Sea-Level Rise
}

By Elizabeth A. Pendleton, E. Robert Thieler, and S. Jeffress Williams

Any use of trade, firm, or product names is for descriptive purposes only and does not imply endorsement by the U.S. Government

\section{Open-File Report 2005-1057}

U.S. Department of the Interior U.S. Geological Survey 


\title{
U.S. Department of the Interior
}

\author{
Gale A. Norton, Secretary
}

\section{U.S. Geological Survey \\ Charles G. Groat, Director}

\author{
U.S. Geological Survey, Reston, Virginia \\ For Additional Information: \\ See the National Park Unit Coastal Vulnerability study at http://woodshole.er.usgs.gov/project-pages/nps.-cvi/, \\ the National Coastal Vulnerability study at http://woodshole.er.usgs.gov/project-pages/cvi/, \\ or view the USGS online fact sheet for this project in PDF formatat http://pubs.usgs.gov/fs/fs095-02/. \\ Channel Islands National Park Web pages are at http://www.nps.gov/chis/index.htm. \\ Contact: \\ http://woodshole.gov/project-pages/nps-cvi/ Telephone: 508-548-8700 \\ Rebecca Beavers \\ National Park Service \\ Natural Resource Program Center \\ Geologic Resources Division \\ P.0. Box 25287 \\ Denver, CO 80225-0287 \\ Rebecca_Beavers@nps.gov \\ Telephone: 303-987-6945
}

For more information on the USGS - the Federal source for science about the Earth, its natural and living resources, natural hazards, and the environment:

World Wide Web: http://www.usgs.gov

Telephone: 1-888-ASK-USGS

Although this report is in the public domain, permission must be secured from the individual copyright owners to reproduce any copyrighted material contained within this report. 


\section{Contents}

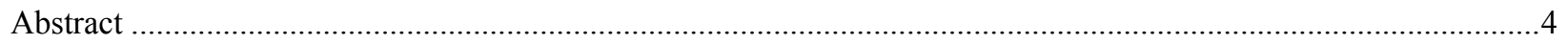

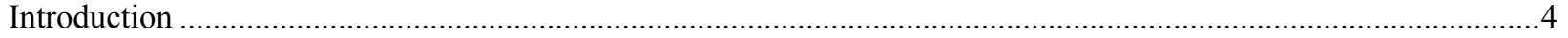

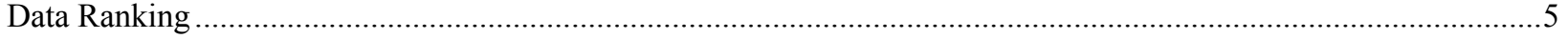

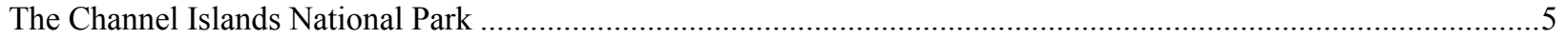

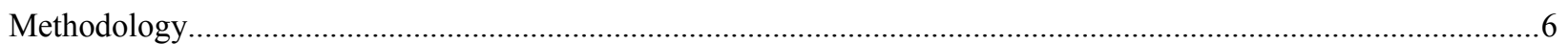

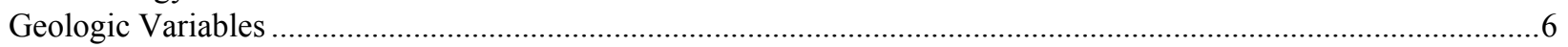

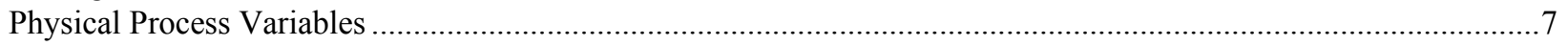

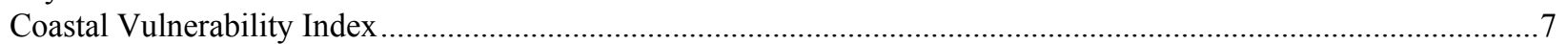

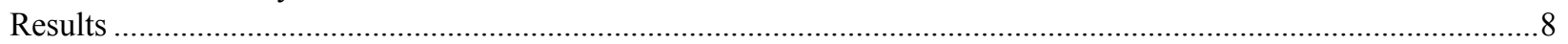

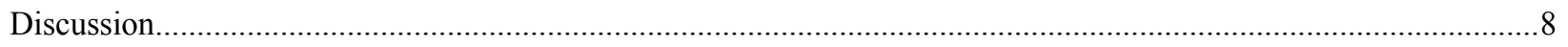

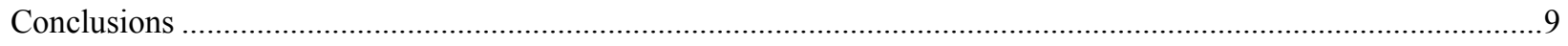

References

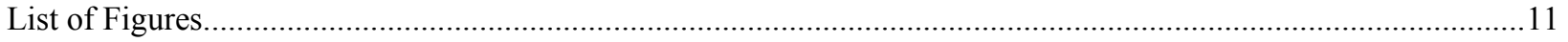

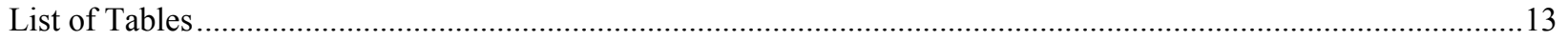




\title{
Coastal Vulnerability Assessment of Channel Islands National Park (CHIS) to Sea-Level Rise
}

\author{
By Elizabeth A. Pendleton, E. Robert Thieler, S. and Jeffress Williams
}

\begin{abstract}
A coastal vulnerability index (CVI) was used to map the relative vulnerability of the coast to future sealevel rise within Channel Islands National Park off the coast of California. The CVI ranks the following in terms of their physical contribution to sea-level rise-related coastal change: geomorphology, regional coastal slope, rate of relative sea-level rise, historical shoreline change rates, mean tidal range and mean significant wave height. The rankings for each input variable were combined, and an index value calculated for 1-minute grid cells covering the park. The CVI highlights those regions where the physical effects of sea-level rise might be the greatest. This approach combines the coastal system's susceptibility to change with its natural ability to adapt to changing environmental conditions, yielding a quantitative, although relative, measure of the park's natural vulnerability to the effects of sea-level rise. The CVI provides an objective technique for evaluation and long-term planning by scientists and park managers. Channel Islands National Park consists of sand and gravel beaches, rock cliffs, and alluvial fans. The areas within the Channel Islands that are likely to be most vulnerable to sea-level rise are areas of unconsolidated sediment where regional coastal slope is low and wave energy is high.
\end{abstract}

\section{Introduction}

The National Park Service (NPS) is responsible for managing nearly 12,000 km (7,500 miles) of shoreline along oceans and lakes. In 2001, the U.S. Geological Survey (USGS), in partnership with the NPS Geologic Resources Division, began conducting hazard assessments of future sea-level change by creating maps to assist NPS in managing its valuable coastal resources. This report presents the results of a vulnerability assessment for Channel Islands National Park, highlighting areas that are likely to be most affected by future sea-level rise..

Global sea level has risen approximately 18 centimeters (7.1 inches) in the past century (Douglas, 1997). Climate models predict an additional rise of $48 \mathrm{~cm}$ (18.9 inches) by 2100 (IPCC, 2002), which is more than double the rate of rise for the 20th century. Potential coastal impacts of sea-level rise include shoreline erosion, saltwater intrusion into groundwater aquifers, inundation of wetlands and estuaries, and threats to cultural and historic resources as well as infrastructure. Predicted accelerated global sea-level rise has generated a need in coastal geology to determine the likely response of a coastline to sea-level rise. However, an accurate and quantitative approach to predicting coastal change is difficult to establish. Even the kinds of data necessary to predict shoreline response are the subject of scientific debate. A number of predictive approaches have been proposed (National Research Council, 1990 and 1995), including:

1. extrapolation of historical data (e.g., coastal erosion rates),

2. static inundation modeling,

3. application of a simple geometric model (e.g., the Bruun Rule),

4. application of a sediment dynamics/budget model, or

5. Monte Carlo (probabilistic) simulation based on parameterized physical forcing variables.

However, each of these approaches has inadequacies or can be invalid for certain applications (National Research Council, 1990). Additionally, shoreline response to sea-level change is further complicated by human modification of the natural coast such as beach nourishment projects, and engineered structures such as seawalls, revetments, groins, and jetties. Understanding how a natural or modified coast will respond to sea-level change is essential to preserving vulnerable coastal resources.. 
The primary challenge in predicting shoreline response to sea-level rise is quantifying the important variables that contribute to coastal evolution in a given area. In order to address the multi-faceted task of predicting sea-level rise impact, the USGS has implemented a methodology to identify areas that may be most vulnerable to future sea-level rise (see Hammar-Klose and Thieler, 2001). This technique uses different ranges of vulnerability (low to very high) to describe a coast's susceptibility to physical change as sea level rises. The vulnerability index determined here focuses on six variables that strongly influence coastal evolution:

1. Geomorphology

2. Historical shoreline change rate

3. Regional coastal slope

4. Relative sea-level change

5. Mean significant wave height

6. Mean tidal range

These variables can be divided into two groups: 1) geologic variables and 2) physical process variables. The geologic variables are geomorphology, historic shoreline change rate, and coastal slope; they account for a shoreline's relative resistance to erosion, long-term erosion/accretion trend, and its susceptibility to flooding, respectively. The physical process variables include significant wave height, tidal range, and sea-level change, all of which contribute to the inundation hazards of a particular section of coastline over time scales from hours to centuries. A relatively simple vulnerability ranking system (Table 1) allows the six variables to be incorporated into an equation that produces a coastal vulnerability index (CVI). The CVI can be used by scientists and park managers to evaluate the likelihood that physical change may occur along a shoreline as sea level continues to rise.

Additionally, NPS staff will be able to incorporate information provided by this vulnerability assessment technique into general management plans.

\section{Data Ranking}

Table 1 shows the six variables described in the Introduction, which include both quantitative and qualitative information. The five quantitative variables are assigned a vulnerability ranking based on their actual values, whereas the non-numerical geomorphology variable is ranked qualitatively according to the relative resistance of a given landform to erosion. Shorelines with erosion/accretion rates between -1.0 and $+1.0 \mathrm{~m} / \mathrm{yr}$ are ranked as being of moderate vulnerability in terms of that particular variable. Increasingly higher erosion or accretion rates are ranked as correspondingly higher or lower vulnerability. Regional coastal slopes range from very high vulnerability, $<4.59$ percent, to very low vulnerability at values $>14.7$ percent. The rate of relative sea-level change is ranked using the modern rate of eustatic rise $(1.8 \mathrm{~mm} / \mathrm{yr})$ as very low vulnerability. Since this is a global or "background" rate common to all shorelines, the sea-level rise ranking reflects primarily local to regional isostatic or tectonic adjustment. Mean wave height contributions to vulnerability range from very low $(<1.1 \mathrm{~m})$ to very high $(>2.6 \mathrm{~m})$. Tidal range is ranked such that microtidal $(<1 \mathrm{~m})$ coasts are very high vulnerability, and macrotidal $(>6 \mathrm{~m})$ coasts are very low vulnerability. This data ranking is based on the methodology of Thieler and Hammar-Klose (1999).

\section{The Channel Islands National Park}

Channel Islands National Park lies off the coast of Southern California (Figure 1). Congress established Channel Islands National Park in 1980 in recognition of their vast natural and cultural resources. The Channel Islands National Marine Sanctuary was also established in 1980 to help preserve the marine ecosystem surrounding the northern Channel Islands.

The northern Channel Islands of Anacapa, Santa Cruz, Santa Rosa, and San Miguel make up a seaward continuation of the Santa Monica Mountains (Seeber and Sorlien, 2000). The islands were uplifted by faulting and folding and are composed of both volcanic (all of Anacapa) and sedimentary units (most of San Miguel) (Shaw and 
Suppe, 1994). During the last glacial maximum when sea level was 90 meters (300 feet) lower than present the northern islands were subaerially exposed as one large island called Santarosae (Vedder and Howell, 1980; Johnson, 1983; Porcasi and others, 1999). The southernmost of the Channel Islands, Santa Barbara, composed of volcanic rocks, lies $65 \mathrm{~km}$ (40 miles) to the southeast of Anacapa and was not part of Santarosae. For more information on geology and the individual islands see: http://www2.nature.nps.gov/geology/parks/chis/.

The Channel Islands contain rookeries for numerous sea bird colonies, six different species of pinnipeds, and over 100 species of organisms that are only found within the Channel Islands (for more information on natural resources within Channel Islands NP see: http://www.nps.gov/chis/rm/Index.htm). Cultural resources within the park date back as far as 10,000 years and include submerged resources such as shipwrecks.

This report addresses the antecedent geology and processes that continually drive coastal evolution over time-scales that sea-level rise will be relevant (the next 50 - 100 years). However, in addition to expected accelerated sea-level rise, the Channel Islands are subject to other geologic hazards that operate on shorter timescales and can result in immediate and major coastal change. These hazards include earthquakes, landslides, and tsunamis, are they are not directly addressed in the methodology of this report.

\section{Methodology}

In order to develop a database for a park-wide assessment of coastal vulnerability, data for each of the six variables mentioned above were gathered from state and federal agencies (Table2). The database is based on that used by Thieler and Hammar-Klose (1999) and loosely follows an earlier database developed by Gornitz and White (1992). A comparable assessment of the sensitivity of the Canadian coast to sea-level rise was presented by Shaw and others (1998).

The database was constructed using a 1:24,000-scale shoreline for Channel Islands that was obtained from the California Spatial Information Library (http://gis.ca.gov/). Data for each of the six variables (geomorphology, shoreline change, coastal slope, relative sea-level rise, significant wave height, and tidal range) were added to the shoreline attribute table using a 1-minute (approximately $1.5 \mathrm{~km}$ ) grid (Figure 2). Next each variable in each grid cell was assigned a vulnerability value from 1-5 ( 1 is very low vulnerability, 5 is very high vulnerability) based on the potential magnitude of its contribution to physical changes on the coast as sea level rises (Table 1).

\section{Geologic Variables}

The geomorphology variable expresses the relative erodibility of different landform types (Table 1). These data were derived using 1-meter resolution 1994 digital orthophotos provided by the California Spatial Information Library (http://gis.ca.gov). In addition, a flight was chartered around the northern islands to obtain oblique aerial photos of the coast in order to verify the geomorphologic classification (Figure 4-8). The Channel Islands contained several geomorphology types, including low to very low vulnerability rock cliffs, moderate vulnerability alluvial deposits and beaches backed by cliffs, and high vulnerability gravel and sand beaches (Figure $3)$.

Shoreline erosion and accretion rates for Channel Islands National Park were estimated using digitized shorelines from 1948 U.S. Coast and Geodetic Survey Charts and 1994 aerial photography (Table 2). Shoreline rates of change (m/yr) were calculated at $200 \mathrm{~m}$ intervals (transects) along sandy beaches of San Miguel Island using Digital Shoreline Analysis System (DSAS) software (http://woodshole.er.usgs.gov/project-pages/dsas/) to derive the rate of shoreline change. Shoreline change rates on San Miguel all fell within the moderate vulnerability category, which is between $-1 \mathrm{~m} / \mathrm{yr}$ and $+1 \mathrm{~m} / \mathrm{yr}$. Rates of shoreline change are expected to be the highest on San Miguel because it has the most erodible coastline and is exposed to the highest wave energy of all the Channel Islands. Most of the shoreline of the Channel Islands has not changed significantly since 1948 because the coast is largely consolidated and rocky; however, there was a major landslide on Santa Cruz in the 1990's that resulted in accretion of the shoreline (Figure 5E). Shoreline erosion and accretion rates in sandy areas on islands other than San Miguel were expected to fall with -1 and $+1 \mathrm{~m} / \mathrm{yr}$ or within the measurement error for an endpoint shoreline change calculation (Figure 9). 
Regional coastal slope is an indication of the relative vulnerability to inundation and the potential rapidity of shoreline retreat because low-sloping coastal regions should retreat faster than steeper regions (Pilkey and Davis, 1987). The regional slope of the coastal zone was calculated from a grid of topographic and bathymetric elevations extending $5 \mathrm{~km}$ landward and seaward of the shoreline. Elevation data were obtained from the National Geophysical Data Center (NGDC) as gridded topographic and bathymetric elevations at 0.1 -meter vertical resolution for 90meter grid cells (Table 2). Regional coastal slopes for the Channel Islands fall within the very low to very high vulnerability category $(<4.55 \%->14.7 \%)$ (Figure 10$)$.

\section{Physical Process Variables}

The relative sea-level change variable is derived from the change in annual mean water elevation over time as measured at tide gauge stations along the coast. The rate of sea-level rise for Santa Barbara, CA (closest to the northern Channel Islands) is $3.22+/-0.99 \mathrm{~mm} / \mathrm{yr}$ based on 27 years of data, and the rate of rise for Newport Beach, CA (closest to Santa Barbara Island) is $2.22+/-0.53$ (Zervas, 2001). This variable inherently includes both eustatic sea-level rise as well as regional sea-level rise due to isostatic and tectonic adjustments of the land surface. Relative sea-level change data are a historical record, and thus portray only the recent sea-level trend $(<150$ years). Relative sea-level rise for Channel Islands falls within the low vulnerability category for Santa Barbara Island and moderate vulnerability for the northern Channel Islands based on water elevation data at Newport Beach and Santa Barbara, respectively (Figure 11). There were no sea-level rise data available for locations within the Channel Islands; therefore mainland approximations were used. Sea-level rise rates for the Channel Islands may be different than the values from Santa Barbara and Newport Beach; however these values are expected to be a close approximation of sea-level rise rate within the Channel Islands. For information on tectonics and land surface adjustments within the Channel Islands readers are directed to Sorlien (1994).

Mean significant wave height is used here as a proxy for wave energy which drives the coastal sediment budget. Wave energy is directly related to the square of wave height;

$$
E=1 / 8 \rho g H^{2}
$$

where $E$ is energy density, $H$ is wave height, $\rho$ is water density and $g$ is acceleration due to gravity. Thus, the ability to mobilize and transport coastal sediments is a function of wave height squared. In this report, we use hindcast nearshore mean significant wave height data for the period 1976-95 obtained from the U.S. Army Corps of Engineers Wave Information Study (WIS) (see references in Hubertz and others, 1996). The model wave heights were compared to historical measured wave height data obtained from the NOAA National Data Buoy Center to ensure that model values were representative of the study area. Mean wave heights for the Channel Islands vary between 2 meters (moderate vulnerability) at San Miguel and western Santa Rosa to just less than 1 meter (very low vulnerability) at Anacapa (Figure 12).

Tidal range is linked to both permanent and episodic inundation hazards. Tide range data were obtained from NOAA/NOS published benchmarks from Bechers Bay on Santa Rosa Island. Mean tidal range was $1.05 \mathrm{~m}$, therefore the Channel Islands were classified as high vulnerability (1.0 - 2.0 meters) with respect to tidal range (Figure 13).

\section{Coastal Vulnerability Index}

The coastal vulnerability index presented here is the same as that used in Thieler and Hammar-Klose (1999) and is similar to that used in Gornitz and others (1994), as well as to the sensitivity index employed by Shaw and others (1998). The CVI allows the six variables to be related in a quantifiable manner that expresses the relative vulnerability of the coast to physical changes due to future sea-level rise. This method yields numerical data that cannot be equated directly with particular physical effects. It does, however, highlight areas where the various effects of sea-level rise may be the greatest. Once each section of coastline is assigned a vulnerability value for each specific data variable, the coastal vulnerability index is calculated as the square root of the product of the ranked variables divided by the total number of variables; 


$$
\mathrm{CVI}=\sqrt{\frac{\left(a * b^{*} c^{*} d * e^{*} f\right)}{6}}
$$

where, $\mathrm{a}=$ geomorphology, $\mathrm{b}=$ shoreline erosion/accretion rate, $\mathrm{c}=$ coastal slope, $\mathrm{d}=$ relative sea-level rise rate, $\mathrm{e}=$ mean significant wave height, and $\mathrm{f}=$ mean tide range. The calculated $\mathrm{CVI}$ value is then divided into quartile ranges to highlight different vulnerabilities within the park. The CVI ranges (low - very high) reported here apply specifically to Channel Islands National Park, and are not comparable to CVI ranges in other parks where the CVI has been employed (i.e. very high vulnerability means the same among parks; it is the numeric values that differ, such that a numeric value that equals very high vulnerability in one park may equal moderate vulnerability in another). To compare vulnerability between coastal parks, the national-scale studies should be used (Thieler and Hammar-Klose, 1999, 2000a, and 2000b). We believe the approach used in this study best describes and highlights the vulnerability specific to individual parks.

\section{Results}

The CVI values calculated for Channel Islands range from 3.46 to 18.97 . The mean CVI value is 8.86 ; the mode is 5.66 and the median is 9.8 . The standard deviation is 3.97 . The 25 th, 50th, and 75 th percentiles are 5.75 , 8.25 and 14.0 , respectively.

Figure 14 shows a map of the coastal vulnerability index for Channel Islands National Park. The CVI scores are divided into low, moderate, high, and very high-vulnerability categories based on the quartile ranges and visual inspection of the data. CVI values below 5.75 are assigned to the low vulnerability category. Values from 5.75 to 8.25 are considered moderate vulnerability. High-vulnerability values lie between 8.26 and 14.0. CVI values above 14.0 are classified as very high vulnerability. Figure 15 shows the percentage of Channel Islands shoreline in each vulnerability category. Over $400 \mathrm{~km}$ (250 miles) of shoreline is evaluated along the Channel Islands National Park. Of this total, twenty-five percent of the mapped shoreline is classified as being at very high vulnerability due to future sea-level rise. Twenty-eight percent is classified as high vulnerability, nineteen percent as moderate vulnerability, and twenty-eight percent as low vulnerability.

\section{Discussion}

The data within the coastal vulnerability index (CVI) show variability at different spatial scales (Figure 14). However, the ranked values for the physical process variables vary less over the extent of the shoreline. The value of the relative sea-level rise variable is low at Santa Barbara Island and moderate vulnerability for the northern islands. The significant wave height vulnerability is moderate to very low. The tidal range is high vulnerability $(1.0-2.0 \mathrm{~m})$ for all of the Channel Islands.

The geologic variables show the most spatial variability and thus have the most influence on CVI variability (Figure 14). Geomorphology in the park includes high vulnerability sand and gravel beach shoreline; moderate vulnerability alluvial fans and beaches backed by cliffs, and low and very low vulnerability rock and cliff features (Figures 3 - 8). Vulnerability assessment based on shoreline change is constant at moderate vulnerability for all of the Channel Islands (Figure 9). Regional coastal slope is in the very low to very high vulnerability range for Channel Islands.

The most influential variables in the CVI are geomorphology, coastal slope, and significant wave height; therefore these may be considered the dominant factors controlling how the Channel Islands coastline will evolve as sea level rises. 


\section{Conclusions}

The coastal vulnerability index (CVI) provides insight into the relative potential of coastal change due to future sealevel rise. The maps and data presented here can be viewed in at least two ways:

1. as an indication of where physical changes are most likely to occur as sea level continues to rise; and

2. as a planning tool for the Channel Islands National Park.

As ranked in this study, geomorphology, regional coastal slope and mean significant wave height and are the most important variables in determining the spatial variability of the CVI for Channel Islands. Tidal range and shoreline change rate do not contribute to the spatial variability in the coastal vulnerability index.

Channel Islands National Park preserves a dynamic natural environment, which must be understood in order to be managed properly. The CVI is one way that park managers can assess objectively the natural factors that contribute to the evolution of the coastal zone, and thus how the park may evolve in the future.

\section{References}

Douglas, B.C., 1997, Global sea rise; A redetermination: Surveys in Geophysics, v. 18, p. 279-292.

Gornitz, V. and White, T.W., 1992, A coastal hazards database for the U.S. West Coast: ORNL/CDIAC-81, NDP-043C, Oak Ridge National Laboratory, Oak Ridge, Tenn.

Gornitz, V.M., Daniels, R.C., White, T.W., and Birdwell, K.R., 1994, The development of a coastal vulnerability assessment database; Vulnerability to sea-level rise in the U.S. southeast: Journal of Coastal Research, Special Issue No. 12, p. 327-338.

Hammar-Klose, E.S., and Thieler, E.R., 2001, Coastal vulnerability to sea-level rise; A preliminary database for the U.S. Atlantic, Pacific, and Gulf of Mexico coasts: U.S. Geological Survey, Digital Data Series, DDS-68, CD-ROM. (Also available on the Web at: http://pubs.usgs.gov/dds/dds68/.)

Hubertz, J.M., Thompson, E.F., and Wang, H.V., 1996, Wave information studies of U.S. coastlines; Annotated bibliography on coastal and ocean data assimilation: U.S. Army Engineer Waterways Experiment Station, WIS Report 36, Vicksburg, 31 p.

IPCC, 2002, Climate Change 2001, The scientific basis; contribution of working group I to the third assessment report of the Intergovernmental Panel on Climate Change: IPCC, Geneva, Switzerland, 563 p. (Also available on the Web at http://www.ipcc.ch.)

Johnson, D.L., 1983, The California continental borderland- landbridges, watergaps and biotic dispersals, in Master, P.M., and Flemming, N.C., eds., Quaternary coastlines and marine archaeology; towards the prehistory of landbridges and continental shelves: Academic Press, London and New York, p. 481-527.

National Research Council, 1990, Managing Coastal Erosion, Washington: National Academy Press, 163 p.

National Research Council, 1995, Beach nourishment and protection, Washington: National Academy Press, 334 p.

Pilkey, O.H., and Davis, T.W., 1987, An analysis of coastal recession models, North Carolina coast, in Nummedal, D., Pilkey, O.H., and Howard, J.D., eds., Sea-level fluctuation and coastal evolution: SEPM (Society for Sedimentary Geology) Special Publications No. 41, Tulsa, Okla., p. 59-68.

Porcasi, P., Porcasi, J.F., and O'Neill, C., 1999, Early Holocene coastlines of the California Bight; The Channel Islands as first visited by humans: Pacific Coast Archaeological Society Quarterly, v. 35, no. 2 and 3, p. 1-24. 
Seeber, L., and Sorlien, C.C., 2000, Listric thrusts in the western Transverse Ranges, California: Geological Society of America Bulletin, v. 112, p. 1067-1079.

Shaw, J.H., and Suppe, J., 1994, Active faulting and growth folding in the eastern Santa Barbara Channel: California, Geological Society of America Bulletin, v. 106, p. 607-626.

Shaw, J., Taylor, R.B., Forbes, D.L., Ruz, M.H., and Solomon, S., 1998, Sensitivity of the Canadian coast to sea-level rise: Geological Survey of Canada Bulletin 505, $114 \mathrm{p}$.

Sorlien, C.C., 1994, Faulting and uplift of the Northern Channel Islands, California, in Halvorson, W.L., and Maender, G.J., eds., The fourth Channel Islands symposium; Update on the status of resources: Santa Barbara Museum of Natural History, Santa Barbara, Calif., p. 281-296.

Thieler, E.R., and Hammar-Klose, E.S., 1999, National assessment of coastal vulnerability to sea-level rise, U.S. Atlantic Coast: U.S. Geological Survey Open-File Report 99-593, 1 sheet. (Available on the Web at http://pubs.usgs.gov/of/of99-593/.)

Thieler, E.R., and Hammar-Klose, E.S., 2000a, National assessment of coastal vulnerability to sea-level rise, U.S. Pacific Coast: U.S. Geological Survey Open-File Report 00-178, 1 sheet. (Available on the Web at http://pubs.usgs.gov/of/of00-178/.)

Thieler, E.R., and Hammar-Klose, E.S., 2000b, National assessment of coastal vulnerability to sea-level rise, U.S. Gulf of Mexico Coast: U.S. Geological Survey Open-File Report 00-179, 1 sheet. (Available on the Web at http://pubs.usgs.gov/of/of00$179 /$.

Vedder, J.G., and Howell, D.G. , 1980, Topographic evolution of the Southern California borderland during the late Cenozoic time, in Power, D.M., ed., The California Islands; proceeding of multi-disciplinary symposium: Santa Barbara Museum of Natural History, Santa Barbara, Calif., p 7-31.

Zervas, C., 2001, Sea level variations of the United States 1854-1999: NOAA Technical Report NOS CO-OPS 36, 201 p. 


\section{List of Figures}

Figure 1. Location of Channel Islands National Park, off the coast of California.

Figure 2. Shoreline grid for Channel Islands National Park. Each cell is approximately I-minute of shoreline and represents a shoreline segment for which each variable is defined.

Figure 3. Coastal Geomorphology for Channel Islands National Park. The colored shoreline represents the variations in coastal geomorphology within the park. High vulnerability geomorphology includes gravel and sand beaches not backed by cliffs. Moderate vulnerability geomorphology consists of alluvial fans and sand beaches immediately backed by cliffs. Low vulnerability geomorphology includes medium cliffs and rock platforms, and very low vulnerability areas consist of vertical and high rock cliffs.

Figure 4. Photos of geomorphologic features on Anacapa Island within Channel Islands NP. All of Anacapa was ranked as very low vulnerability with respect to geomorphology: A) East Anacapa, B) Middle Anacapa, and C) West Anacapa.

Figure 5. Photos of geomorphologic features on Santa Cruz Island within Channel Islands NP: A) a moderate vulnerability beach backed by cliffs, B) low vulnerability medium cliffs, C) very low vulnerability high vertical cliffs, D) Prisoners Bay (moderate vulnerability, E) a recent landslide (moderate - low vulnerability), and F) Scorpions (moderate - low vulnerability).

Figure 6. Photos of geomorphologic features on Santa Rosa Island within Channel Islands NP: A) a high vulnerability beach, B) moderate vulnerability beach backed by cliffs, C) low - very low vulnerability cliffs, D) moderate vulnerability beach backed by cliffs near Sandy Point, E) low vulnerability terraced cliffs, F) very low vulnerability cliffs at Carrington Point, and G) moderate - high vulnerability beach at Bechers Bay.

Figure 7. Photos of geomorphologic features on San Miguel Island within Channel Islands NP: A) a high vulnerability beach, B) and C) moderate vulnerability beach backed by cliffs, D) Point Bennet (high vulnerability beaches and low vulnerability rock platforms), E) Harris Point (low vulnerability), and F) low vulnerability cliffs with small interspersed pocket beaches

Figure 8. Photo Santa Barbara Island within Channel Islands NP. This volcanic island was classified as low (east side) to very low vulnerability (north and west sides) (NPS photo).

Figure 9. Shoreline change for Channel Islands National Park. The colored shoreline represents the estimated rate of shoreline erosion or accretion. Based on calculated rates for San Miguel Island, all of the Channels Islands were classified as moderate vulnerability.

Figure 10. Regional coastal slope for Channel Islands National Park. The colored shoreline represents the regional slope of the land, $5 \mathrm{~km}$ landward and seaward of the shoreline. Very high vulnerability coastal slopes are generally away from the mountains in the northern islands and very low vulnerability is concentrated on Santa Cruz Island.

Figure 11. Rate of relative sea-level rise for Channel Islands National Park. The colored shoreline represents the ranked rate of rise for Santa Barbara and Newport Beach. All of northern Channel Islands are ranked as moderate vulnerability and Santa Barbara Island is ranked as low vulnerability with respect to sea-level rise.

Figure 12. Mean significant wave heights for Channel Islands National Park. The colored shoreline represents the ranked mean significant heights within the park. The highest wave heights are on San Miguel and Santa Rosa Island and the lowest wave heights are on Anacapa Island. 
Figure 13. Mean Tidal Range for Channel Islands National Park. The colored shoreline represents the ranked mean tidal range for Channel Islands. All of Channel Islands National Park is ranked as moderate vulnerability with respect to tidal range.

Figure 14. Relative Coastal Vulnerability for Channel Islands National Park. The colored shoreline represents the relative coastal vulnerability index (CVI) determined from the six variables. The very high vulnerability shoreline is located along sandy stretches of coast where regional coastal slope vulnerability is high and significant wave heights are highest. The low vulnerability shoreline is located along rock cliffs where coastal slope is steep and wave heights are low.

Figure 15. Percentage of Channel Islands National Park shoreline in each CVI category. 


\section{List of Tables}

Table 1. Ranges for Vulnerability Ranking of Variables on the Pacific Coast.

Table 2. Sources of Data 


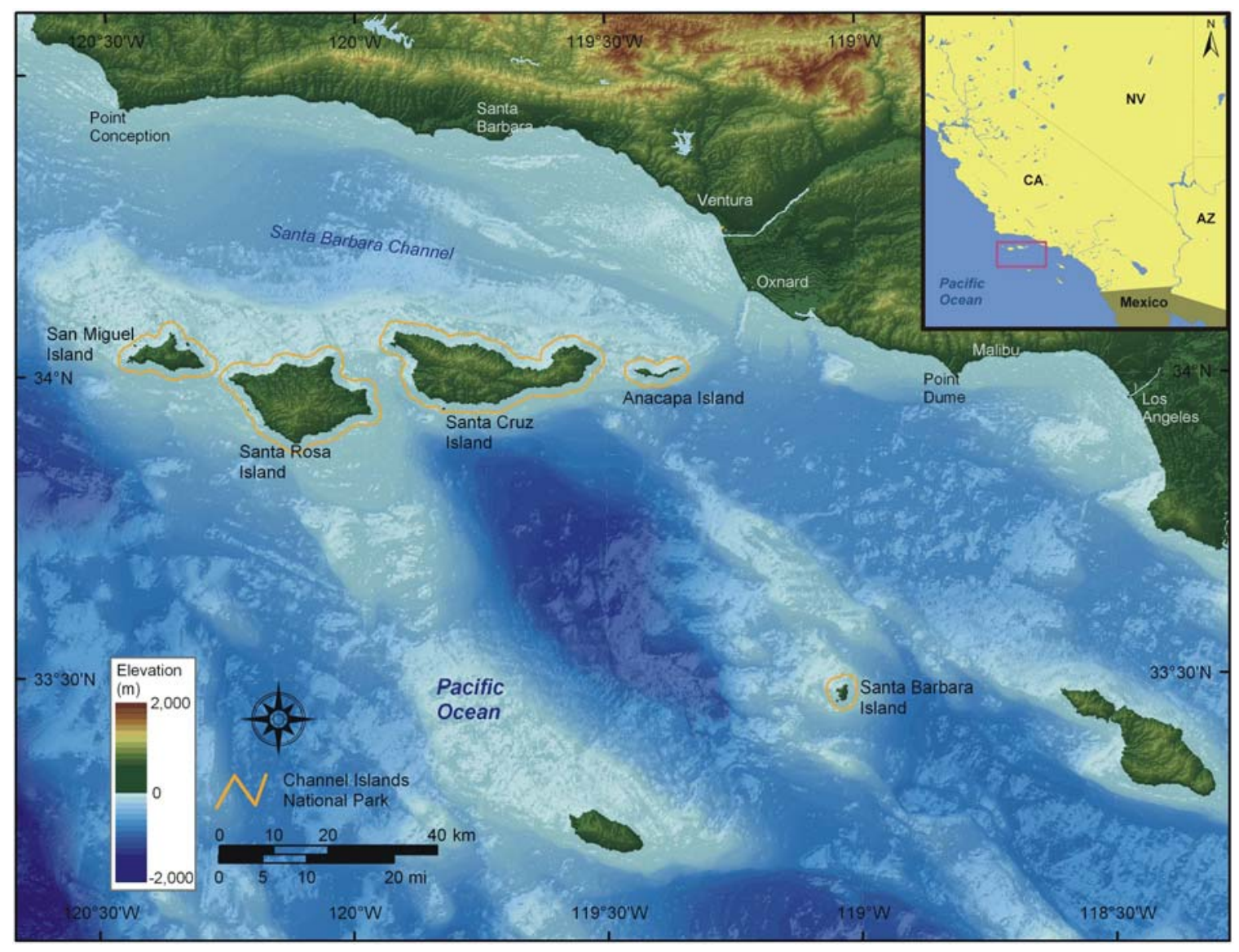

Figure 1. Location of Channel Islands National Park, off the coast of California. 


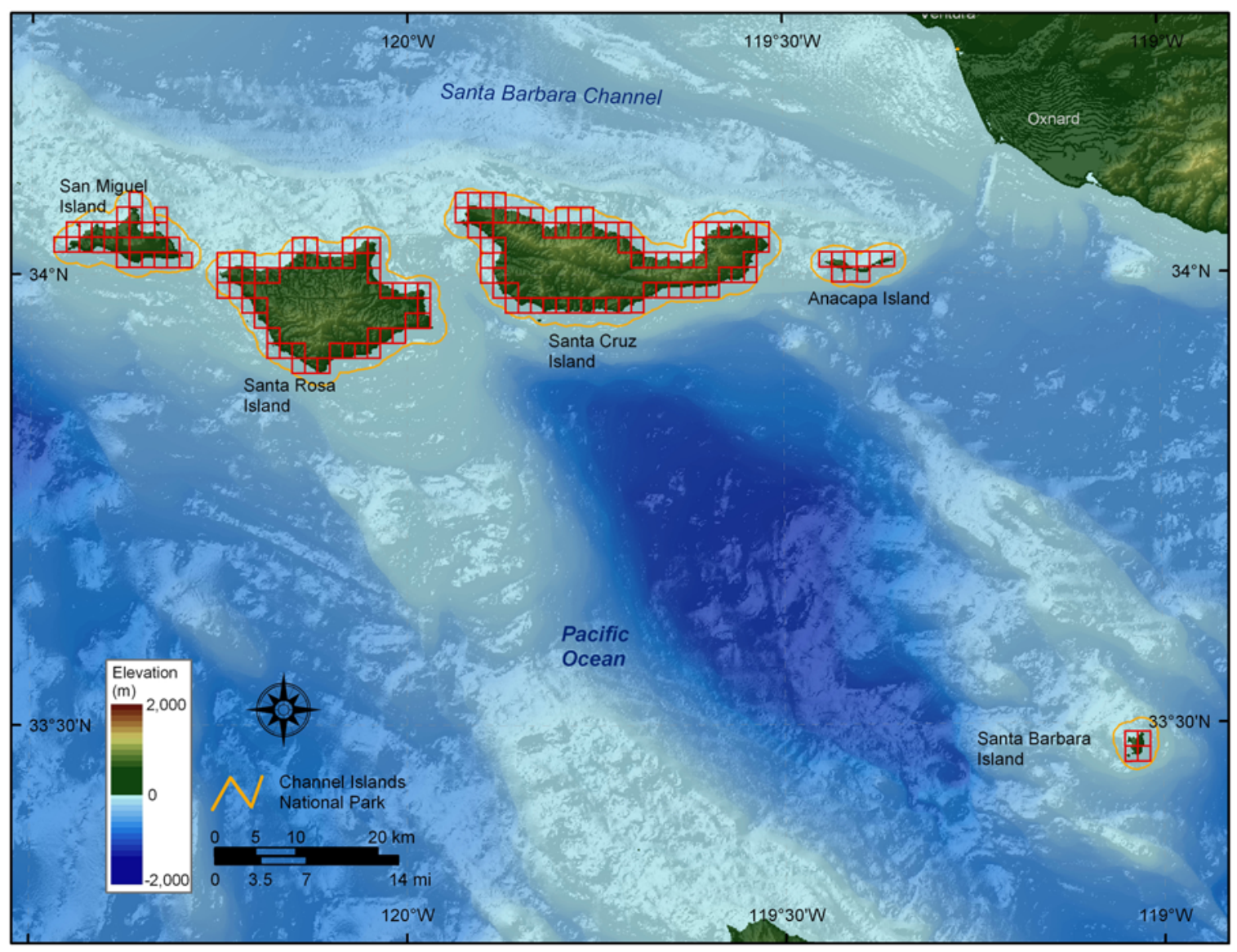

Figure 2. Shoreline grid for Channel Islands National Park. Each cell is approximately I-minute of shoreline and represents a shoreline segment for which each variable is defined. 


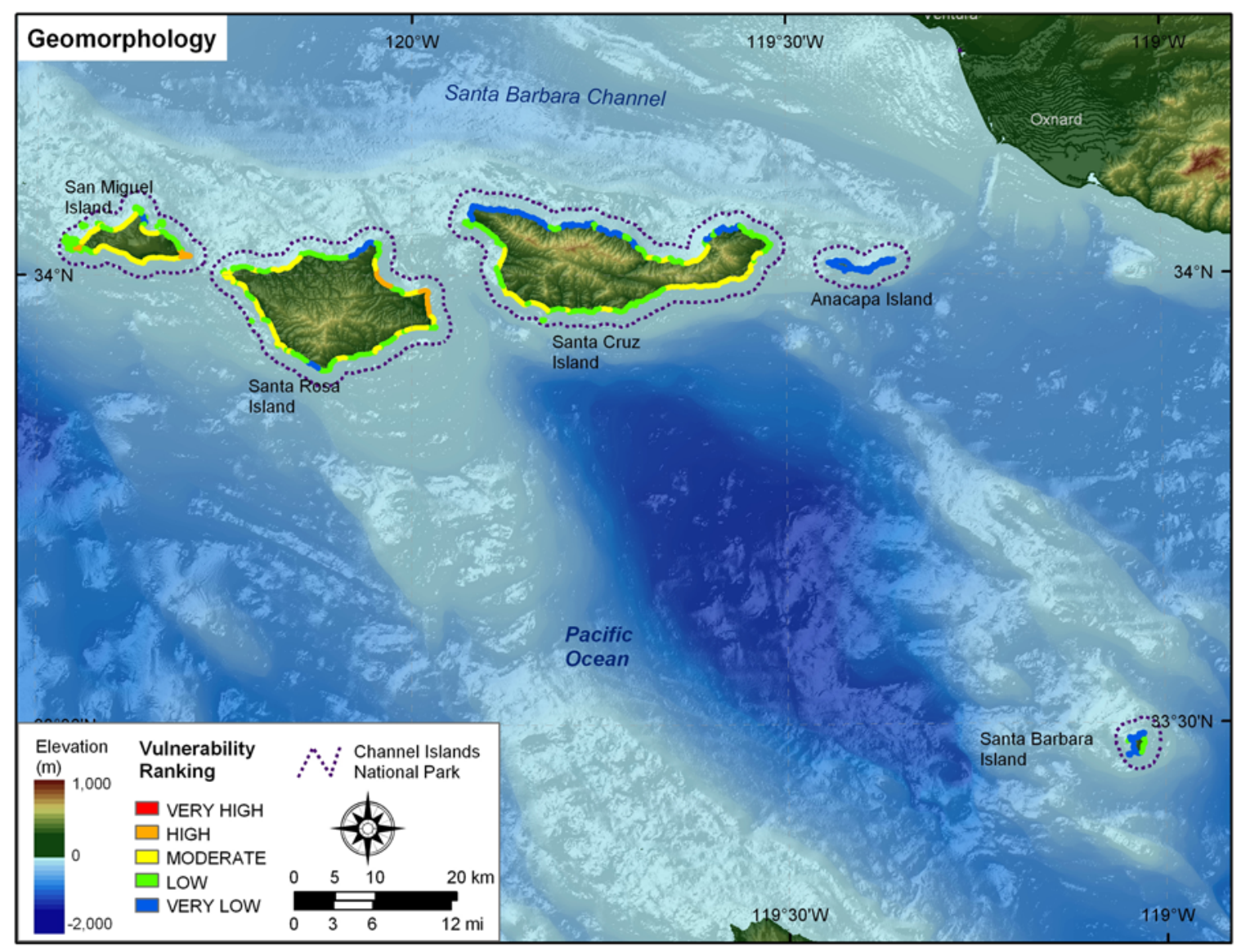

Figures 3. Coastal Geomorphology for Channel Islands National Park. The colored shoreline represents the variations in coastal geomorphology within the park. High vulnerability geomorphology includes gravel and sand beaches not backed by cliffs. Moderate vulnerability geomorphology consists of alluvial fans and sand beaches immediately backed by cliffs. Low vulnerability geomorphology includes medium cliffs and rock platforms, and very low vulnerability areas consist of vertical and high rock cliffs. 

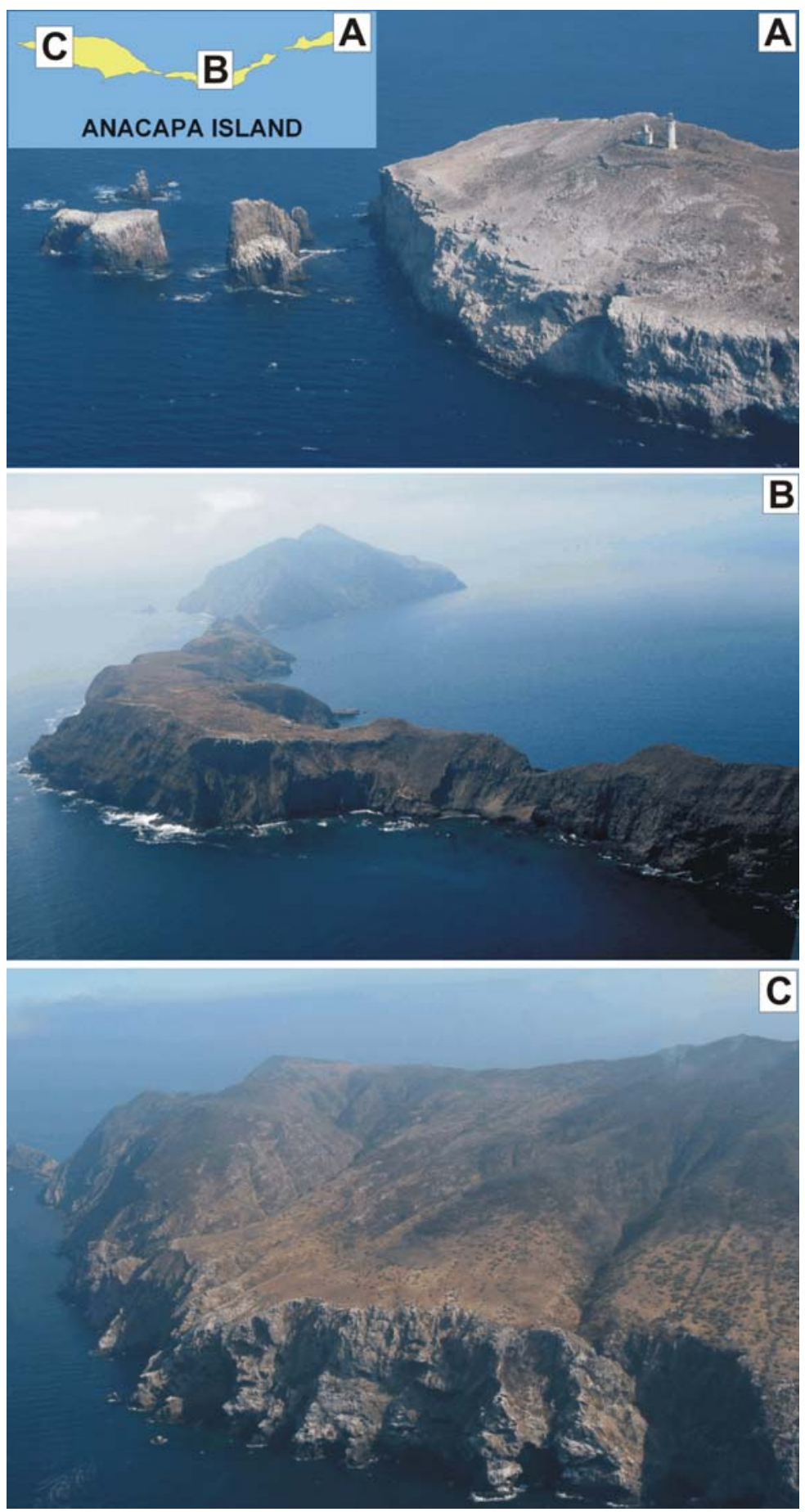

Figure 4. Photos of geomorphologic features on Anacapa Island within Channel Islands NP. All of Anacapa was ranked as very low vulnerability with respect to geomorphology: A) East Anacapa, B) Middle Anacapa, and C) West Anacapa. 


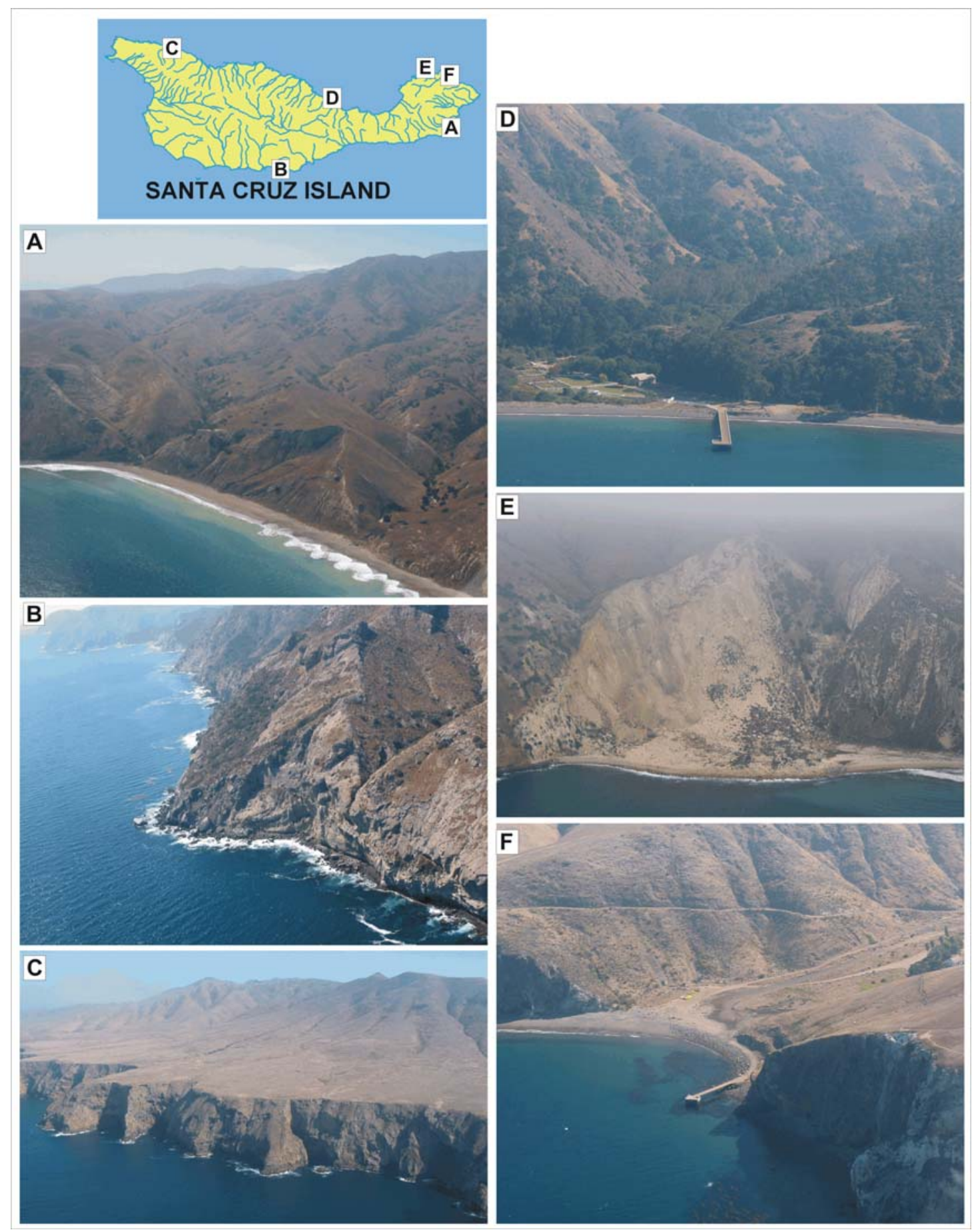

Figure 5. Photos of geomorphologic features on Santa Cruz Island within Channel Islands NP: A) a moderate vulnerability beach backed by cliffs, B) low vulnerability medium cliffs, C) very low vulnerability high vertical cliffs, D) Prisoners Bay (moderate vulnerability, E) a recent landslide (moderate - low vulnerability), and F) Scorpions (moderate - low vulnerability). 


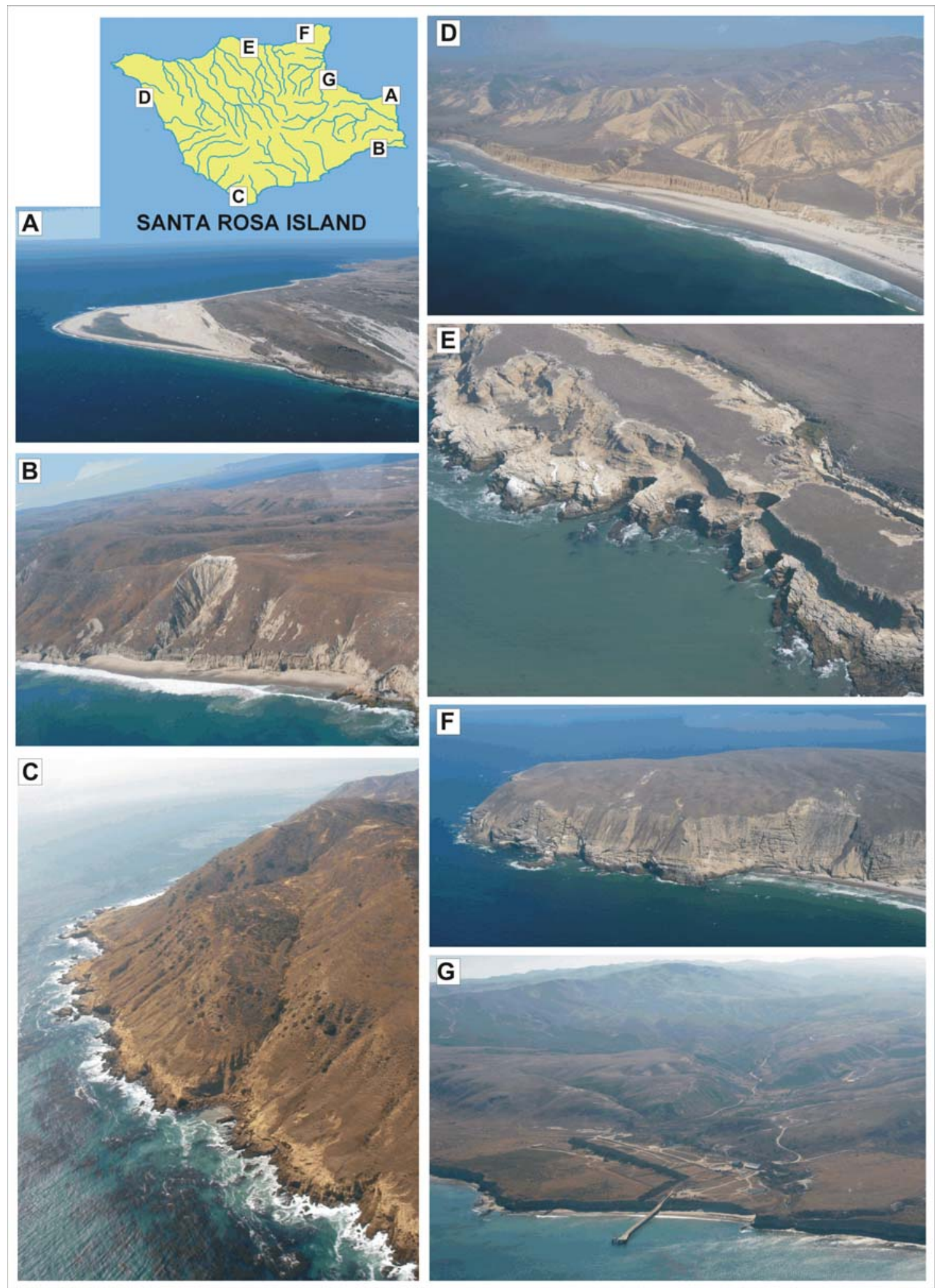

Figure 6. Photos of geomorphologic features on Santa Rosa Island within Channel Islands NP: A) a high vulnerability beach, B) moderate vulnerability beach backed by cliffs, C) low - very low vulnerability cliffs, D) moderate vulnerability beach backed by cliffs near Sandy Point, E) low vulnerability terraced cliffs, F) very low vulnerability cliffs at Carrington Point, and G) moderate - high vulnerability beach at Bechers Bay. 

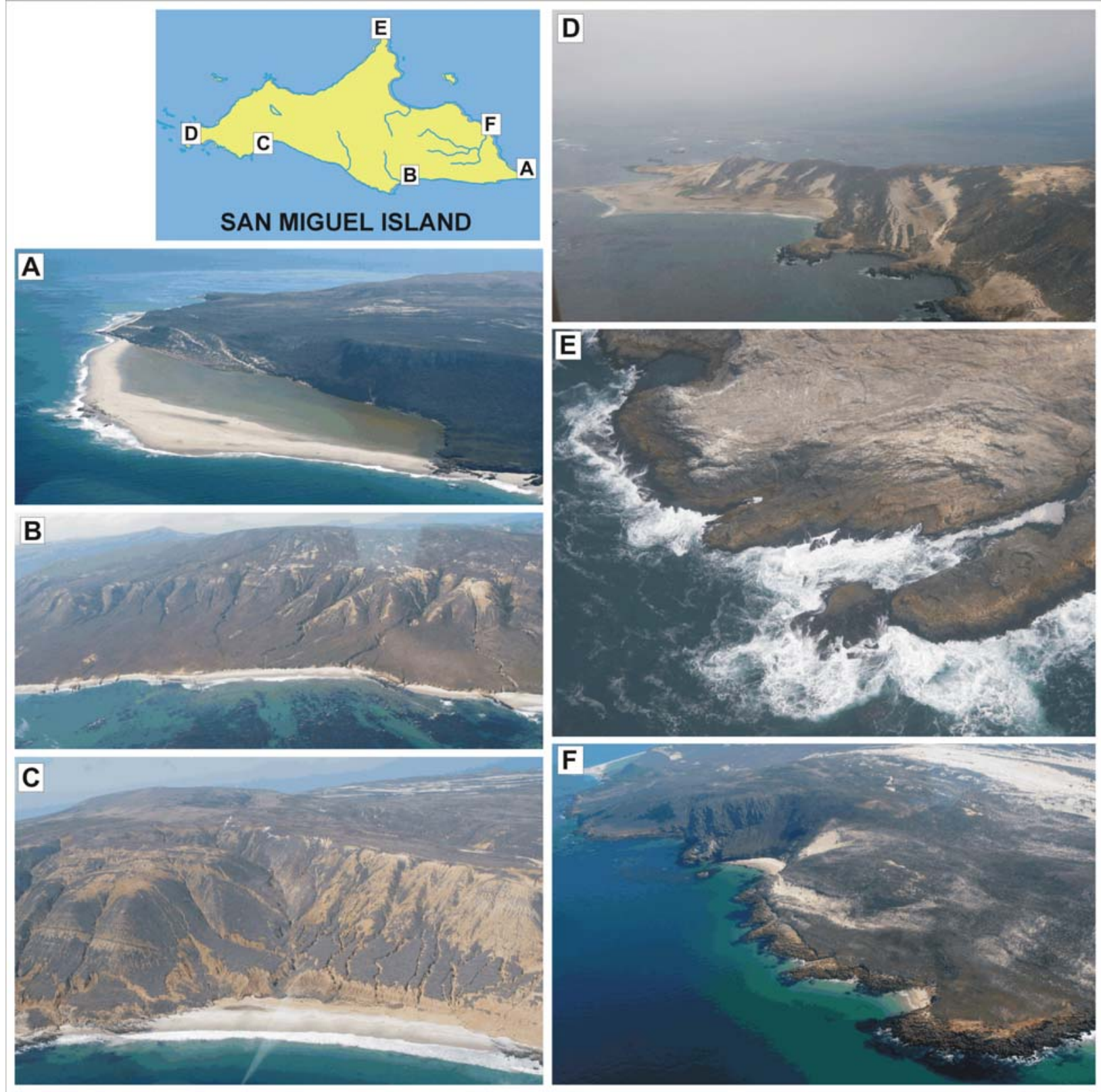

Figure 7. Photos of geomorphologic features on San Miguel Island within Channel Islands NP: A) a high vulnerability beach, B) and C) moderate vulnerability beach backed by cliffs, D) Point Bennet (high vulnerability beaches and low vulnerability rock platforms), E) Harris Point (low vulnerability), and F) low vulnerability cliffs with small interspersed pocket beaches. 


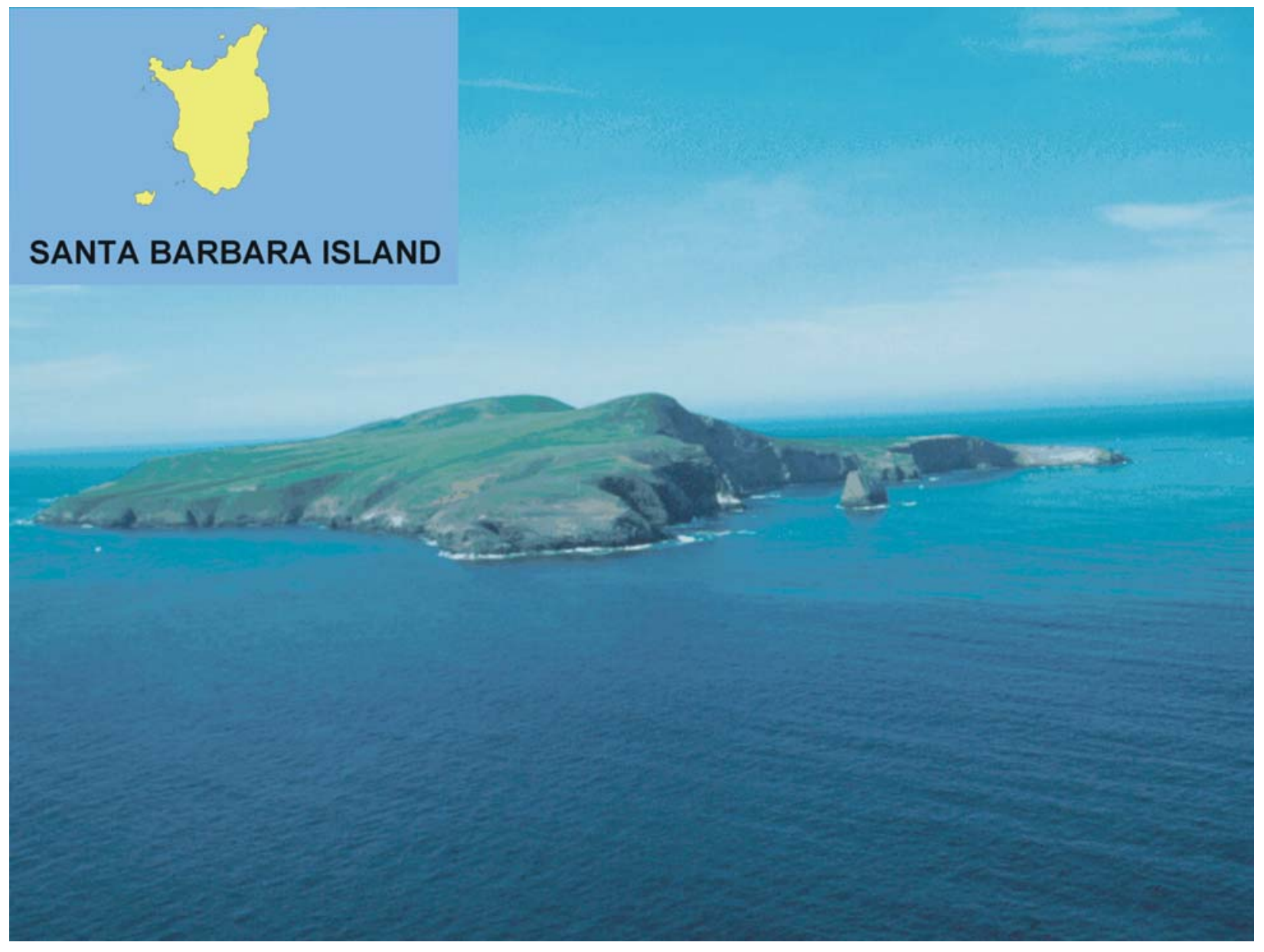

Figure 8. Photo Santa Barbara Island within Channel Islands NP. This volcanic island was classified as low (east side) to very low vulnerability (north and west sides) (NPS photo). 


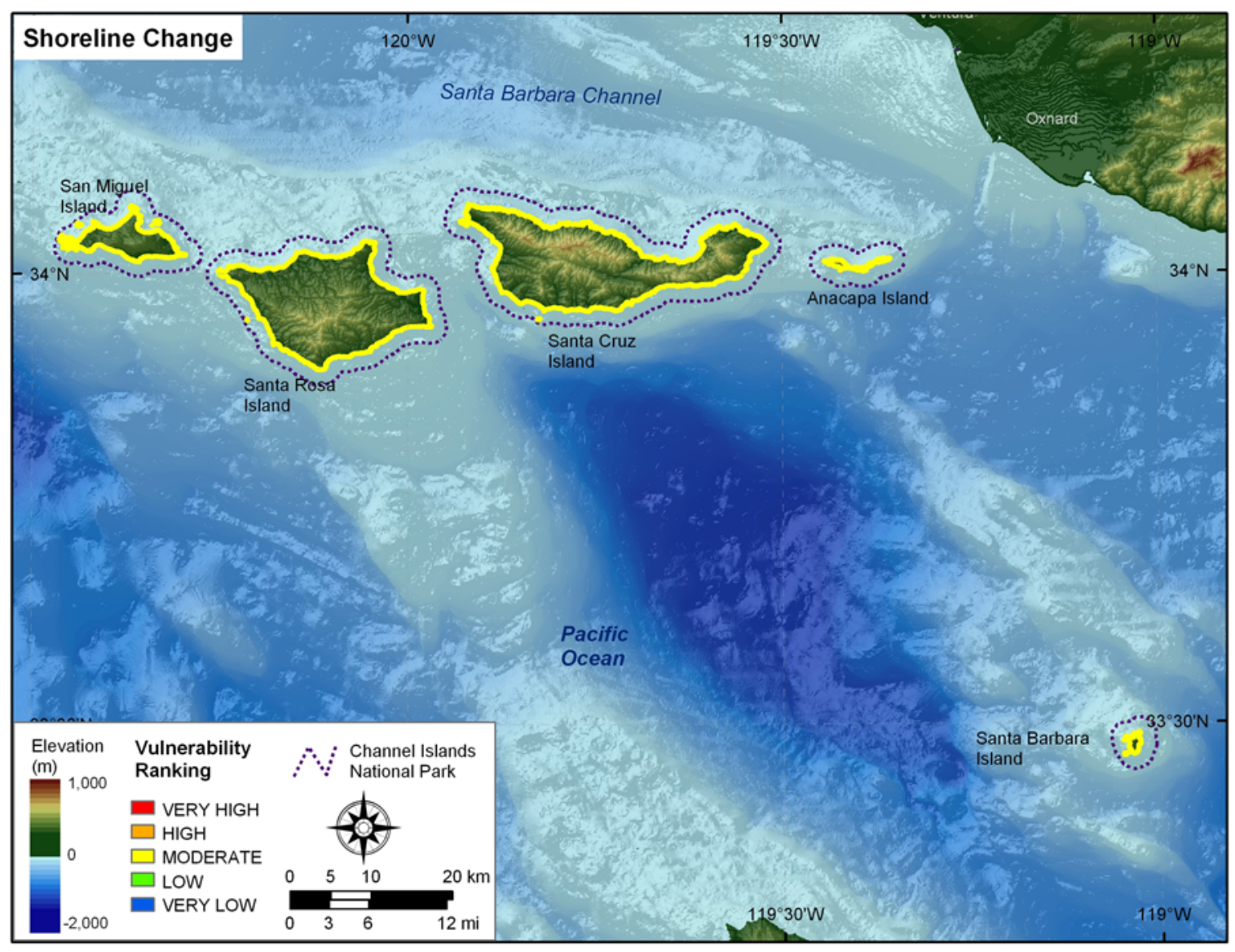

Figure 9. Shoreline change for Channel Islands National Park. The colored shoreline represents the estimated rate of shoreline erosion or accretion. Based on calculated rates for San Miguel Island, all of the Channels Islands were classified as moderate vulnerability. 


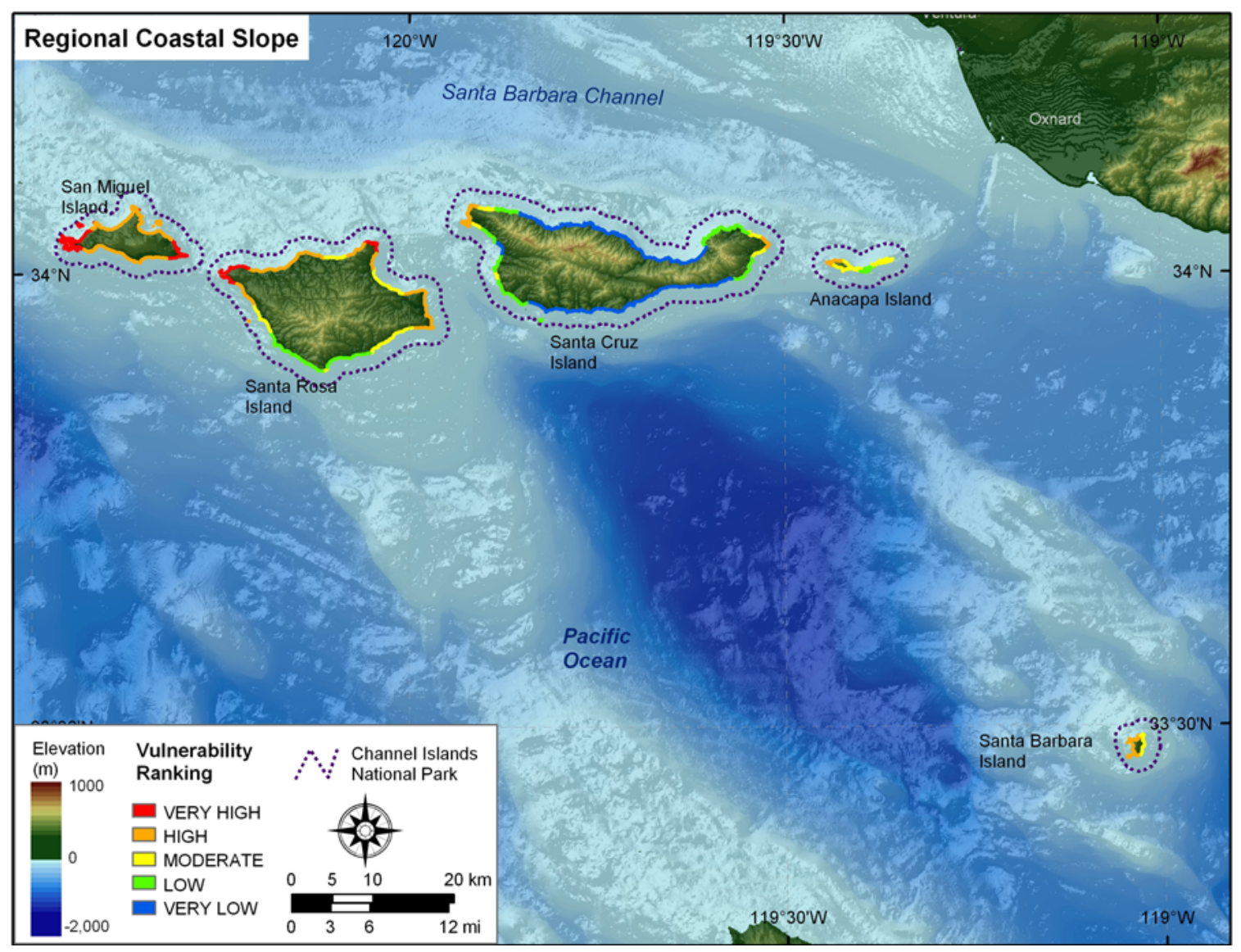

Figure 10. Regional coastal slope for Channel Islands National Park. The colored shoreline represents the regional slope of the land, $5 \mathrm{~km}$ landward and seaward of the shoreline. Very high vulnerability coastal slopes are generally away from the mountains in the northern islands and very low vulnerability is concentrated on Santa Cruz Island. 


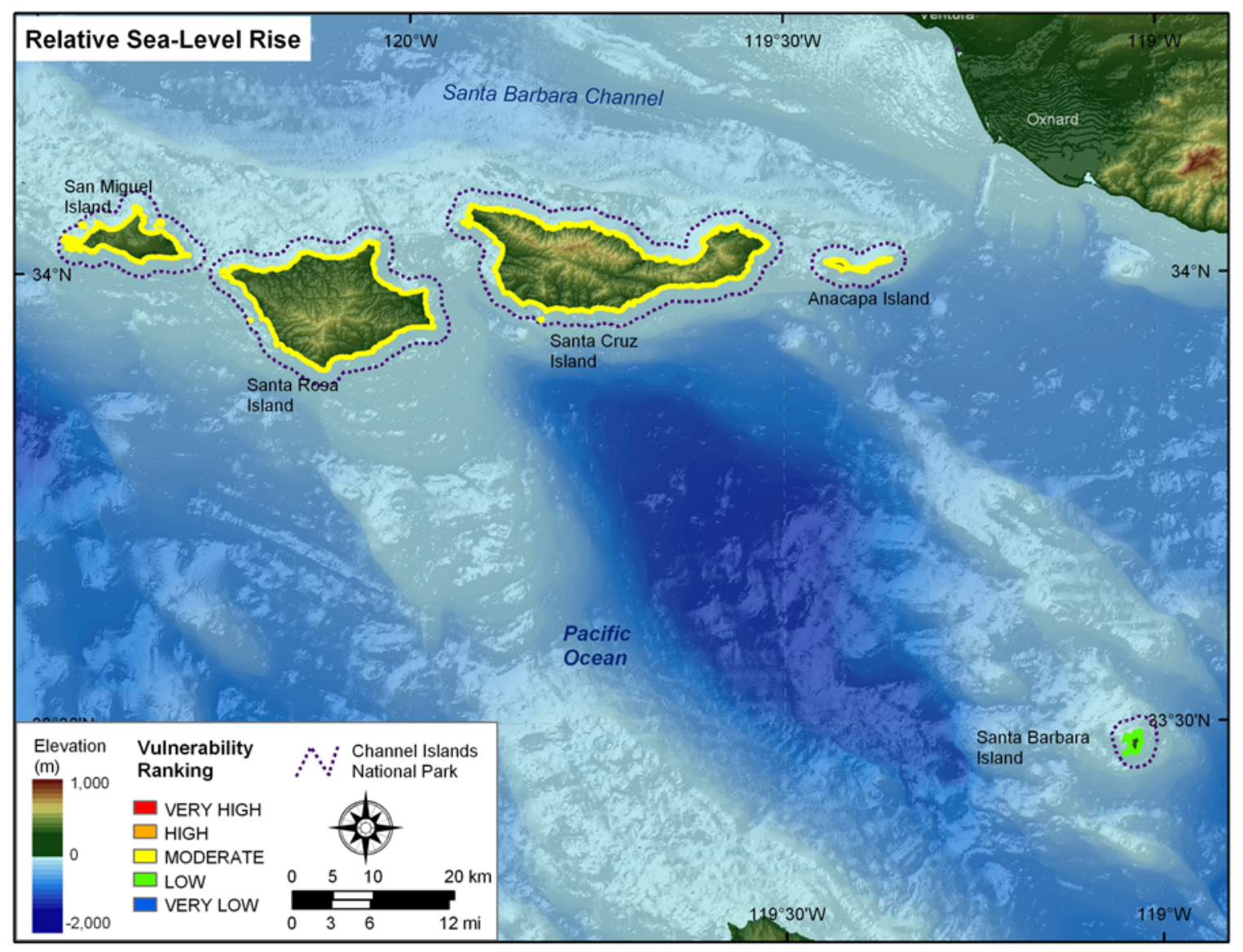

Figure 11. Rate of relative sea-level rise for Channel Islands National Park. The colored shoreline represents the ranked rate of rise for Santa Barbara and Newport Beach. All of northern Channel Islands are ranked as moderate vulnerability and Santa Barbara Island is ranked as low vulnerability with respect to sea-level rise. 


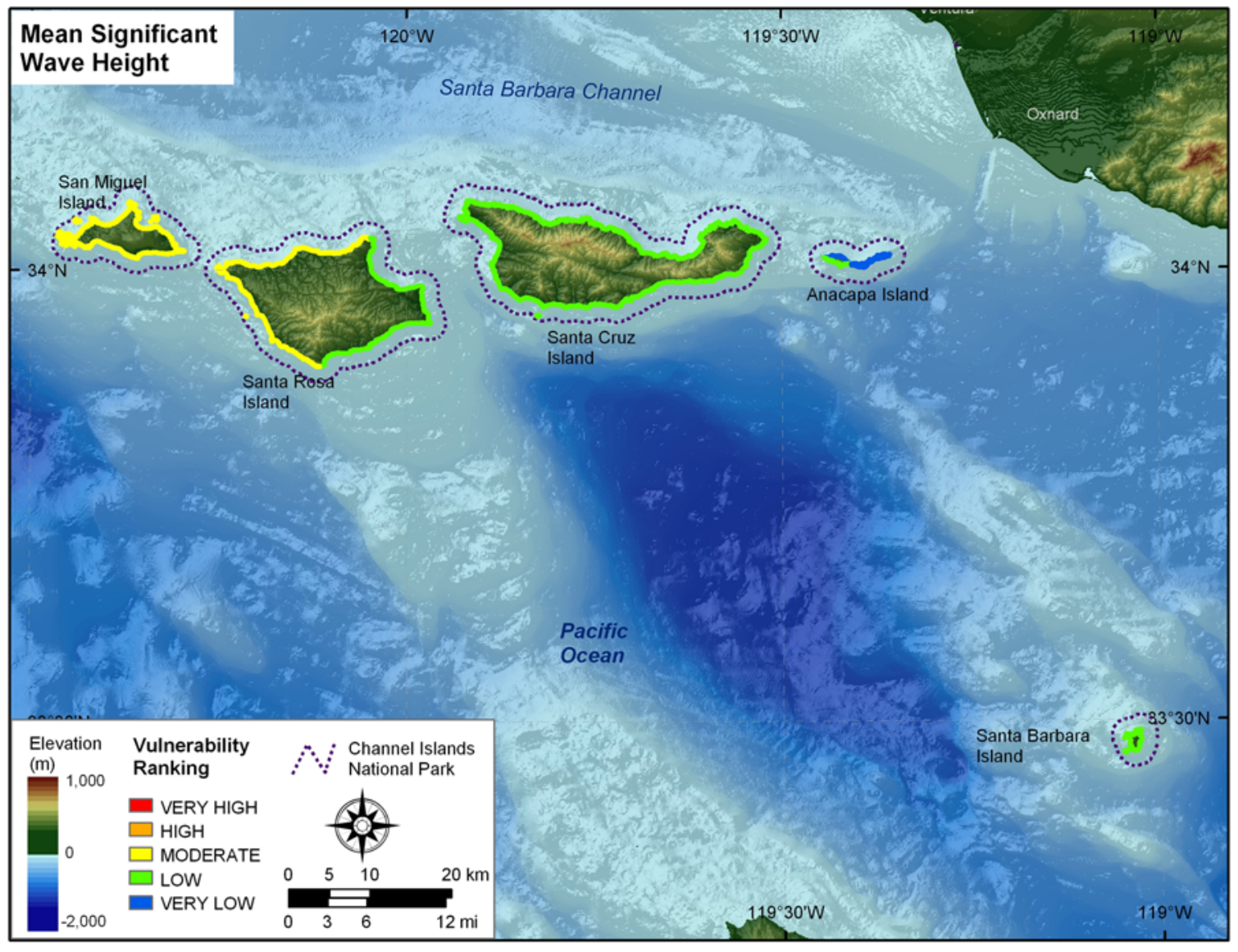

Figure 12. Mean significant wave heights for Channel Islands National Park. The colored shoreline represents the ranked mean significant heights within the park. The highest wave heights are on San Miguel and Santa Rosa Island and the lowest wave heights are on Anacapa Island. 


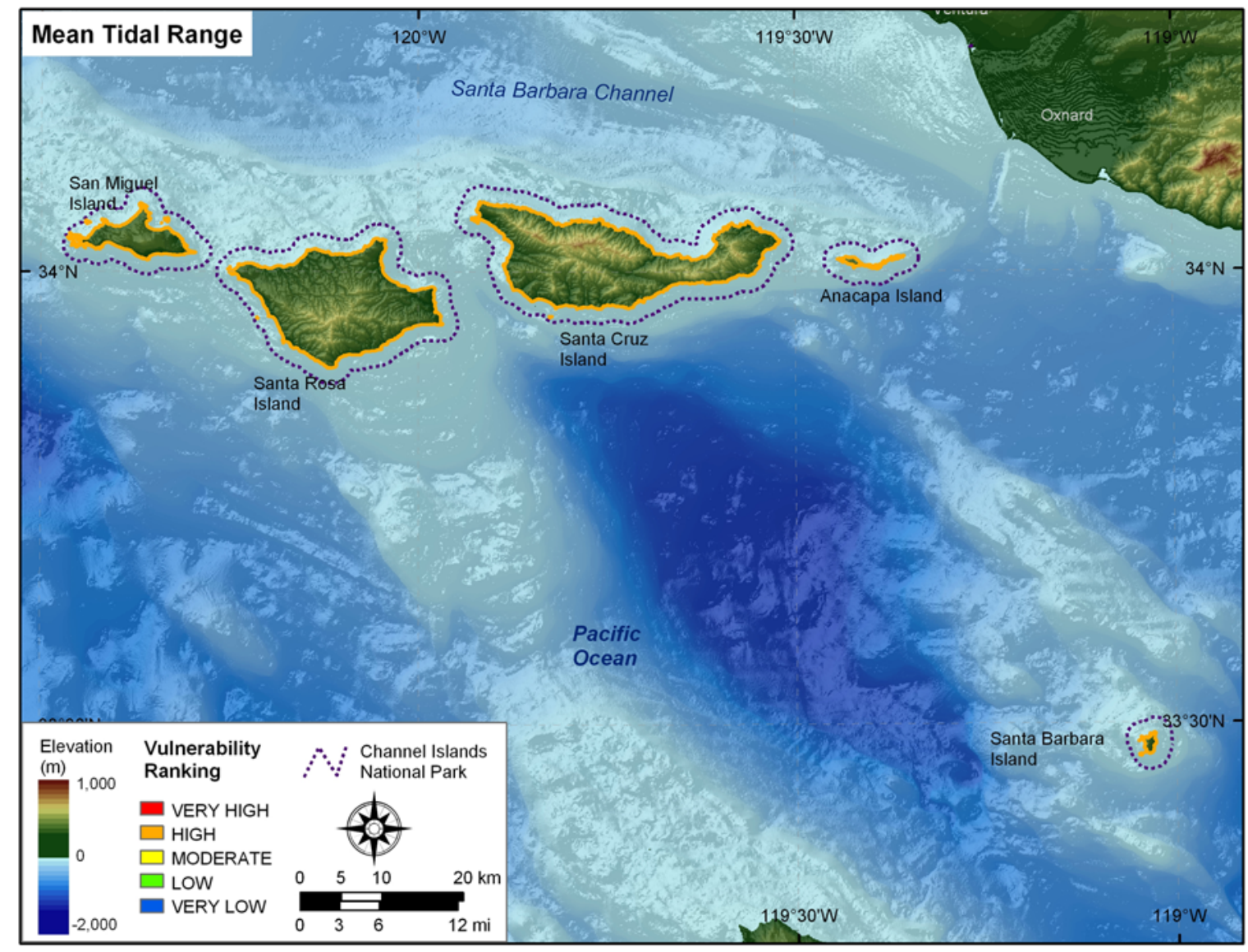

Figure 13. Mean Tidal Range for Channel Islands National Park. The colored shoreline represents the ranked mean tidal range for Channel Islands. All of Channel Islands National Park is ranked as moderate vulnerability with respect to tidal range. 


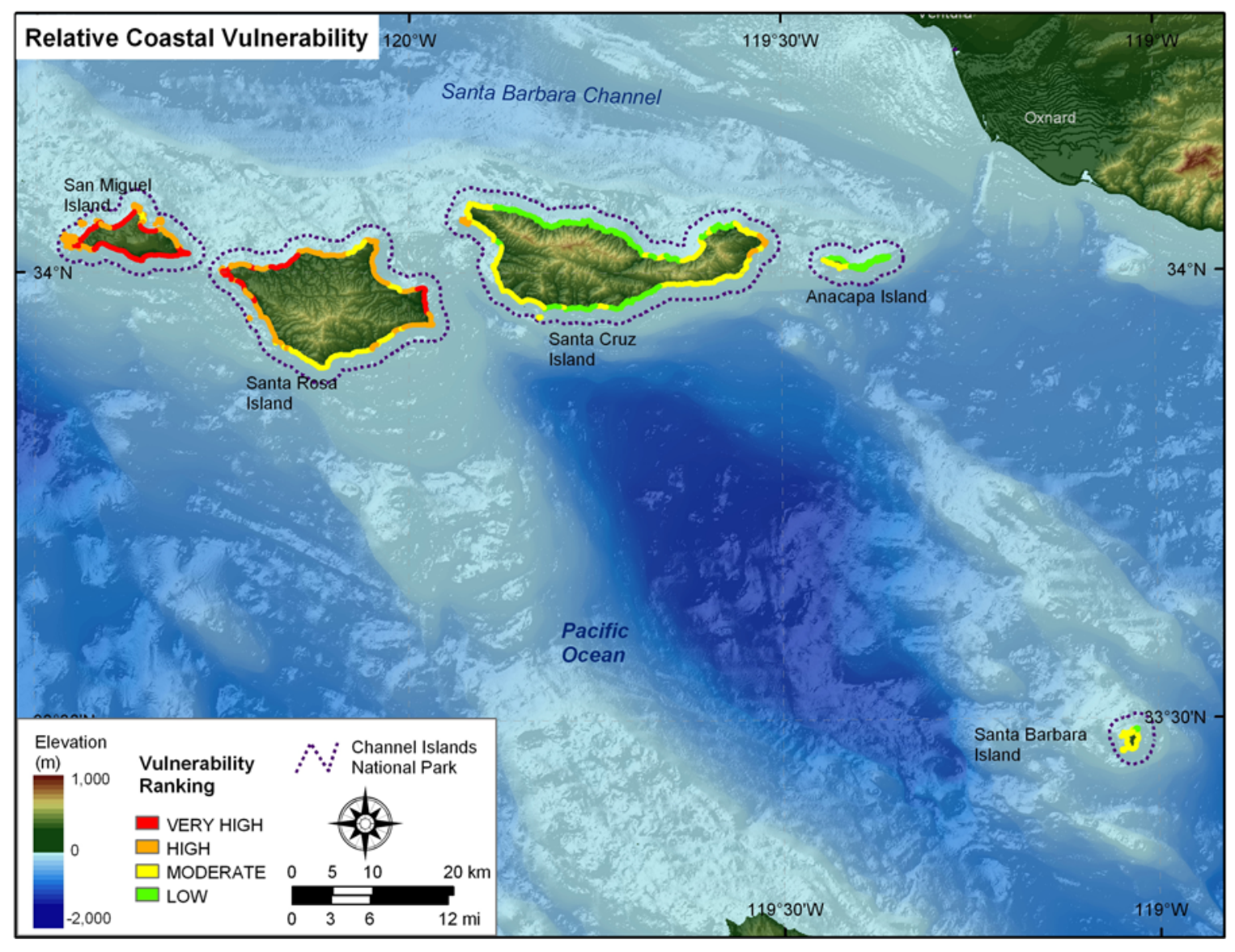

Figure 14. Relative Coastal Vulnerability for Channel Islands National Park. The colored shoreline represents the relative coastal vulnerability index (CVI) determined from the six variables. The very high vulnerability shoreline is located along sandy stretches of coast where regional coastal slope vulnerability is high and significant wave heights are highest. The low vulnerability shoreline is located along rock cliffs where coastal slope is steep and wave heights are low. 


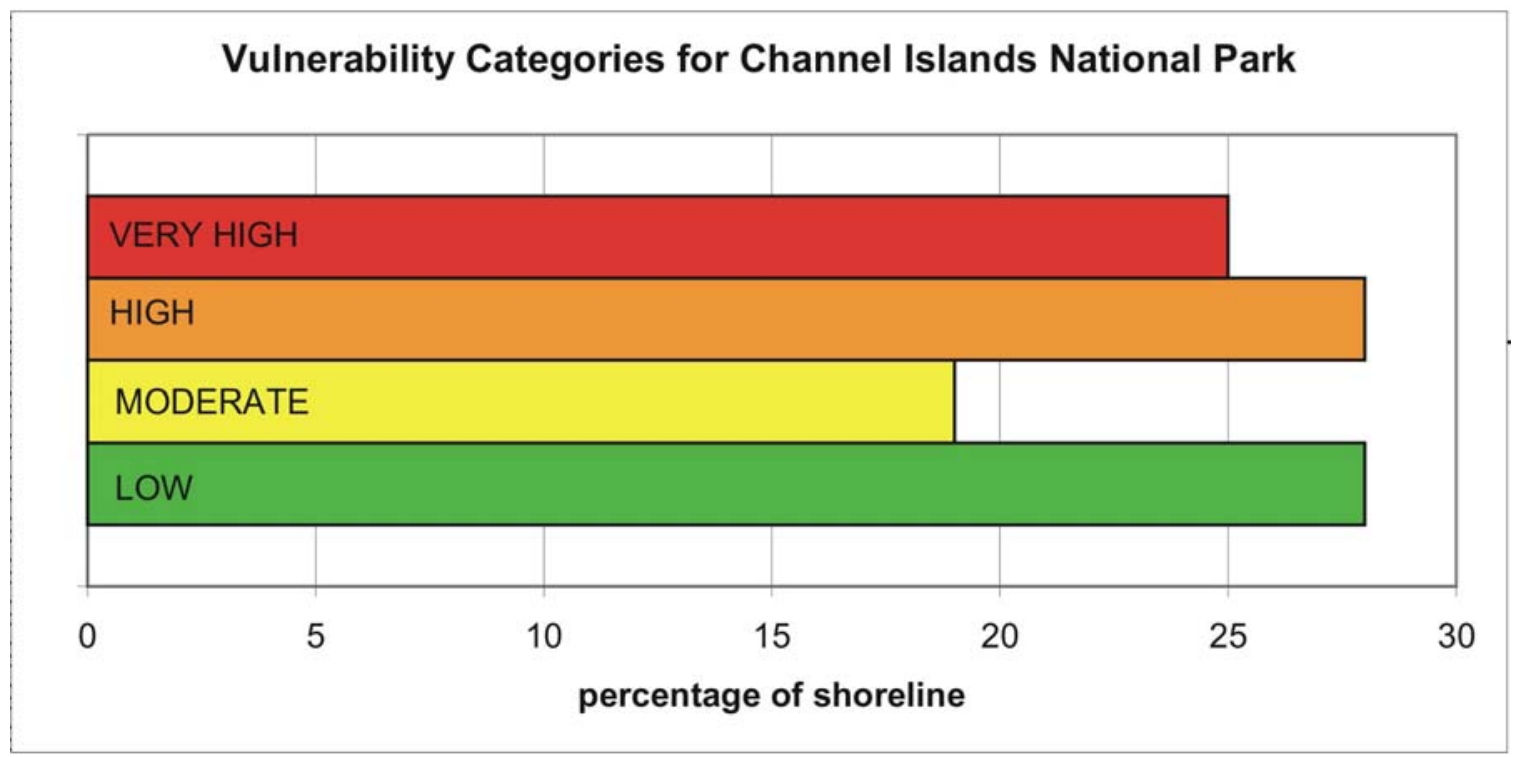

Figure 15. Percentage of Channel Islands National Park shoreline in each CVI category. 
Table 1. Ranges for Vulnerability Ranking of Variables on the US Pacific Coast

\begin{tabular}{|c|c|c|c|c|c|}
\hline Variables & $\begin{array}{c}\text { Very Low } \\
1\end{array}$ & $\begin{array}{c}\text { Low } \\
2\end{array}$ & $\begin{array}{c}\text { Moderate } \\
\mathbf{3}\end{array}$ & $\begin{array}{c}\text { High } \\
4\end{array}$ & $\begin{array}{l}\text { Very High } \\
5\end{array}$ \\
\hline GEOMORPHOLOGY & $\begin{array}{l}\text { Rocky } \\
\text { cliffed } \\
\text { coasts, } \\
\text { Fjords }\end{array}$ & $\begin{array}{l}\text { Medium } \\
\text { cliffs, } \\
\text { Indented } \\
\text { coasts }\end{array}$ & $\begin{array}{l}\text { Low cliffs, } \\
\text { Glacial drift, } \\
\text { Alluvial } \\
\text { plains }\end{array}$ & $\begin{array}{l}\text { Cobble Beaches, } \\
\text { Estuary, Lagoon }\end{array}$ & $\begin{array}{c}\text { Barrier beaches, Sand beaches, } \\
\text { Salt marsh, Mud flats, Deltas, } \\
\text { Coral reefs }\end{array}$ \\
\hline $\begin{array}{l}\text { SHORELINE EROSION/ } \\
\text { ACCRETION (m/yr) }\end{array}$ & $>2.0$ & $1.0-2.0$ & $-1.0-1.0$ & $-2.0--1.0$ & $<-2.0$ \\
\hline COASTAL SLOPE (\%) & $>14.70$ & $10.90-14.69$ & $7.75-10.89$ & $4.60-7.74$ & $<4.59$ \\
\hline $\begin{array}{l}\text { RELATIVE SEA-LEVEL } \\
\text { CHANGE }(\mathrm{mm} / \mathrm{yr})\end{array}$ & $<1.8$ & $1.8-2.5$ & $2.5-3.0$ & $3.0-3.4$ & $>3.4$ \\
\hline $\begin{array}{l}\text { MEAN WAVE HEIGHT } \\
(\mathrm{m})\end{array}$ & $<1.1$ & $1.1-2.0$ & $2.01-2.25$ & $2.26-2.6$ & $>2.6$ \\
\hline MEAN TIDE RANGE (m) & $>6.0$ & $4.0-6.0$ & $2.0-4.0$ & $1.0-2.0$ & $<1.0$ \\
\hline
\end{tabular}




\begin{tabular}{|c|c|c|}
\hline Variables & Source & $\begin{array}{c}\text { URL } \\
\text { (Not all sources are downloadable) }\end{array}$ \\
\hline GEOMORPHOLOGY & $\begin{array}{l}\text { 1994 1-meter resolution } \\
\text { digital orthophotos from } \\
\text { the California Spatial } \\
\text { Information Library }\end{array}$ & http://gis.ca.gov/ \\
\hline $\begin{array}{c}\text { SHORELINE } \\
\text { EROSION/ACCRETION } \\
(\mathrm{m} / \mathrm{yr})\end{array}$ & $\begin{array}{l}\text { San Miguel shoreline } \\
\text { change data were digitized } \\
\text { in house from US Coast } \\
\text { and Geodetic Survey } \\
\text { charts (1948) and aerial } \\
\text { photography (1994). }\end{array}$ & $\begin{array}{l}\text { http://historicals.ncd.noaa.gov/historicals/histmap.asp } \\
\text { http://gis.ca.gov/ }\end{array}$ \\
\hline COASTAL SLOPE (\%) & $\begin{array}{l}\text { NGDC Coastal Relief } \\
\text { Model Vol } 06\end{array}$ & http://www.ngdc.noaa.gov/mgg/coastal/coastal.html \\
\hline $\begin{array}{l}\text { RELATIVE SEA-LEVEL } \\
\text { CHANGE }(\mathrm{mm} / \mathrm{yr})\end{array}$ & $\begin{array}{l}\text { NOAA Technical Report } \\
\text { NOS CO-OPS } 36 \text { SEA } \\
\text { LEVEL VARIATIONS } \\
\text { OF THE UNITED } \\
\text { STATES 1854-1999 } \\
\quad \text { (Zervas, 2001) }\end{array}$ & http://www.co-ops.nos.noaa.gov/publications/techrpt36doc.pdf \\
\hline $\begin{array}{l}\text { MEAN WAVE HEIGHT } \\
(\mathrm{m})\end{array}$ & $\begin{array}{l}\text { Pacific Coast WIS Data } \\
\text { and National Data Buoy } \\
\text { Center }\end{array}$ & $\begin{array}{l}\text { http://frf.usace.army.mil/wis/wis main.html } \\
\text { http://seaboard.ndbc.noaa.gov/ }\end{array}$ \\
\hline MEAN TIDE RANGE (m) & $\begin{array}{l}\text { NOAA/NOS CO-OPS } \\
\text { Historical Water Level } \\
\text { Station Index }\end{array}$ & http://www.co-ops.nos.noaa.gov/usmap.html \\
\hline
\end{tabular}

